\title{
STRATEGI PENGEMBANGAN KAWASAN WISATA PANTAI PANJANG BENGKULU, DITINJAU DARI PERSPEKTIF WISATAWAN DAN MASYARAKAT LOKAL
}

\author{
Handika Fikri Pratama \\ Alumni Sekolah Tinggi Pariwisata Bandung \\ Budiman Sakti \\ Dosen Fakultas Ekonomi Unihaz Bengkulu
}

\begin{abstract}
ABSTRAK
Handika Fikri Pratama dan Budiman Sakti: Penelitian ini bertujuan untuk mengidentifikasi potensi daya tarik wisata, mengkaji kondisi lingkungan internal (berupa kekuatan dan kelemahannya) dan kondisi lingkungan eksternal (berupa peluang dan ancaman), serta mengkaji program pengembangan pariwisata yang sesuai di Pantai Panjang berbasis kepada perspektif wisatawan dan masyarakat lokal. Metode analisis yang digunakan dalam penelitian ini, yaitu analisis diskritif untuk mengidentifikasi ketersediaan sarana prasarana dan potensi serta daya trarik wisata dan analisis kuantitatif dengan bantuan Matrik IFAS dan matrix EFAS. Jumlah responden yang diambil berdasarkan accidental sampling berjumlah 100 responden. Hasil penelitian menunjukan bahwa potensi daya tarik wisata yang terdapat di Pantai Panjang dengan skor faktor internal sebesar $+0,910$ dan faktor eksternal dengan nilai skor sebesar $+1,90$. Dengan demikian posisinya dalam matrik grand strategy (matrik internal-external) berada pada posisi strategi pertumbuhan dengan menempati sel 1 dalam matrik. Posisi sel satu menunjukan strategi tumbuh dan bina (Rapid growth strategy), strategi untuk meningkatkan laju pertumbuhan kunjungan wisatawan dengan waktu lebih cepat (tahun kedua lebih besar dari tahun pertama dan selanjutnya), peningkatan kualitas yang menjadi faktor kekuatan untuk memaksimalkan pemanfaatan semua peluang (grand strategy). usaha pengembangan Tapak Paderi dan Pantai Jakat yang berkelanjutan (sustainable).
\end{abstract}

\begin{abstract}
Handika Fikri Pratama dan Budiman Sakti: The purpose of this study was to identify potential tourist attraction, reviewing internal environmental conditions (such as their strengths and weaknesses) and external environmental conditions (such as opportunities and threats), and review the appropriate tourism development program in the Long Beach-based to tourists and local community perspective. The analytical method used in this study, namely diskritif analysis to identify the availability of infrastructure and the potential and power trarik travel and quantitative analysis with the help of Matrix IFAS and EFAS matrix. The number of respondents who were taken by accidental sampling of 100 respondents. The results showed that the potential tourist attraction located in Long Beach with a score of +0.910 internal factors and external factors with a score of +1.90 . Thus the position in the grand strategy matrix (matrix internal-external) are in a position with a growth strategy occupies one cell in the matrix. A cell's position one shows the strategy to grow and establish (Rapid growth strategy), strategies to increase the growth rate of tourist arrivals with a faster time (the second year is greater than the first year and thereafter), improving the quality of that factor into force in order to maximize the utilization of all the opportunities (grand strategy). Tapak Padri development efforts and Beach Jakat sustainable (sustainable).
\end{abstract}

Key Words: Grand Strategy, Tourism Development Program

\section{PENDAHULUAN}

Kota Bengkulu mempunyai potensi wisata yang sangat potensial untuk dikembangkan, salah satunya adalah Pantai Panjang yang terletak di sisi barat Kota Bengkulu yang jaraknya dari pusat kota hanya lebih kurang 2 kilo meter. Letak yang strategis dan tidak jauh dari pusat kota merupakan kekuatan yang dimiliki selain indahnya panorama alam dan laut sehingga perlu mendapatkan perhatian serius dari Pemerintah Propinsi dan Kota Bengkulu untuk menjadikan Pantai Panjang sebagai kawasan wisata yang menarik para wisatawan untuk datang ke Kota Bengkulu. Ada enam fokus bentuk wisata yang akan dikembangkan di kawasan Pantai Panjang yaitu: wisata pantai, wisata urban, wisata rakyat, wisata air, wisata ekoturism dan wisata pelabuhan. Pengembangan wisata kawasan pantai Kota Bengkulu ini diharapkan mampu meningkatkan Pendapatan Asli Daerah (PAD) dan kesejahteraan masyarakat

Peningkatan jumlah kunjungan wisatawan ke Kota Bengkulu memberikan kontribusi besar dalam perkembangan pariwisata. Hal ini dapat dilihat data dari Dinas Kebudayaan dan Ekonomi Kreatif Kota Bengkulu mengenai data kunjungan wisman dan wisnus tahun 2007-2014 yang menunjukkan ada kenaikan jumlah kunjungan wisatawan setiap tahunnya rerata sebesar 19,71 persen, yang akan 
memberikan peluang besar bagi peningkatan pendapatan masyarakat maupun Pendapatan Asli Daerah (PAD) Kota Bengkulu. Berdasarkan hasil riset yang dilakukan di kantor Dinas Kebudayaan dan Pariwisata Kota Bengkulu terhadap data jumlah kunjungan wisatawan Mancanegara dan Nusantara dari tahun 2007 sampai dengan tahun 2014, adalah sebagai berikut:

Tabel 1. Jumlah Kunjungan Wisatawan Mancanegara dan Nusantara di Kota Bengkulu, Tahun $2007-2014$.
\begin{tabular}{|c|c|c|c|c|c|}
\hline No. & Tahun & Mancanegara & Nusantara & Total & Pertumbuhan (\%) \\
\hline 1 & 2007 & 301 & 109.747 & 110.048 & - \\
2 & 2008 & 326 & 214.452 & 214.778 & 95,17 \\
3 & 2009 & 430 & 210.321 & 210.751 & $-1,87$ \\
4 & 2010 & 443 & 225.051 & 225.494 & 7,00 \\
5 & 2011 & 523 & 226.753 & 227.276 & 31,79 \\
6 & 2012 & 551 & 299.193 & 299.744 & $-16,47$ \\
7 & 2013 & 796 & 249.569 & 250.365 & 21,46 \\
8 & 2014 & 895 & 303.186 & 304.081 & \\
\hline
\end{tabular}

Sumber : Dinas Pariwisata dan Ekonomi Kreatif Kota Bengkulu, 2015

Pantai Panjang Bengkulu sebagai leading sektor pariwisata dapat mendorong pengembangan industri pariwisata, karena lokasinya tidak jauh dari pusat kota Bengkulu tetapi potensi ini belum dapat berkembang sesuai dengan potensi yang dimilikinya. Kondisi inilah yang menyebabkan Pantai Panjang Bengkulu masih sangat jauh tertinggal dibanding dengan atraksi wisata alam yang ada di daerah di Indonesia seperti wisata pantai Propinsi Bali, NTT, Lampung, dan propinsi lainnya. Potensi yang dimiliki oleh Pantai Panjang masih memerlukan strategi pengembangan yang tepat agar dapat menjadikan Pantai Panjang sebagai daerah wisata yang paling diminati di Kota Bengkulu.

Untuk pengembangan kawasan wisata Pantai Panjang yang terpadu dan terkoneksi dengan pengambangan wisata lainnya yang ada di Kota Bengkulu, sangat dibutuhkan suatu strategi untuk pengembangan pariwisata di Pantai Panjang secara kontinuitas. Potensi wisata ini didukung adanya tempat wisata sejarah Benteng Marlbrough yang merupakan benteng sejarah peninggalan koloni Inggeris. Pasir putih yang terhampar luas, hamparan pohon pinus yang tumbuh disepanjang kawasan pantai, laut dan ombak yang cukup besar dan aman untuk wisata surfing dan tempat wisata mandi laut untuk para wisatawan terutama pada waktu hari liburan menambah indah dan semaraknya Pantai Panjang..

Berdasarkan Rencana Induk Pengembangan Objek Wisata (RIPOW 2013) Pantai Panjang Kota Bengkulu, telah dibuat master plan pengembangan kawasan wisata Pantai Panjang yang menitikberatkan pada pembangunan sarana dan prasarana penunjang objek wisata. Fokus penelitian ini adalah meneliti bagaimana persepsi dari para wisatawan dan masyarakat lokal terhadap rencana pengembangan wisata Pantai Panjang. Dilihat potensi wisata alam yang dimiliki, perlu adanya perhatian dan aksi langsung dari pihak pemerintah Propinsi Bengkulu dan Kota Bengkulu untuk membuat rencana induk tentang "Strategi Pengembangan Kawasan Wisata Pantai Panjang Kota Bengkulu" yang terpadu dan berkesinambungan dari pemerintah berdasarkan aspirasi/persepsi wisatawan dan masyarakat lokal supaya objek wisata ini dapat terjaga dengan baik.

Permasalahan utama yang dihadapi dalam pengembangan kawasan Pantai Panjang adalah: masih rendahnya kesadaran dan dukungan masyarakat dan para wisatawan, perencanaan yang belum terpadu antara pemerintah Propinsi Bengkulu dengan Pemerintah Kota Bengkulu mengenai status penguasaan dan pengembangan kawasan wisata Pantai Panjang, dan masih kurangnya atraksi/hiburan dikawasan ini untuk menarik minat kunjungan wisata ke Pantai Panjang Bengkulu.

\section{LANDASAN TEORI}

Tribe's (1997: 13) mendefinisikan strategi perencanaan masa depan yang diinginkan dan desain sesuai dengan kondisi lingkungan disekitanya, sedangkan Rangkuti (1996:37) mengatakan bahwa strategi adalah alat untuk mencapai tujuan Selanjutnya Pender dan Sharpley $(2005 ; 120)$, mengemukakan ada empat elemen kunci dari strategi perusahaan, yaitu:

1) Misi: menentukan apa usaha sebuah organisasi untuk mencapai tujuan dan arah strategi yang telah ditentukan.

2) Analisis Strategis: memberikan informasi kepada organisasi mengenai kekuatan dan kelemahan sumber daya internal, yaitu peluang dan ancaman yang jelas dalam lingkungan luar.

3) Strategis Pilihan: sebuah organisasi harus menghasilkan, mengevaluasi dan memilih sebuah strategi yang tepat.

4) Strategis Implementasi: menunjukkan bagaimana sebuah organisasi menempatkan strategi dalam praktik.

Suwantoro, 1997 (88-89), mendefinisikan pengembangan adalah suatu proses atau cara menjadikan sesuatu menjadi maju, baik, sempurna, dan berguna. Menurutnya ada beberapa bentuk produk pariwisata 
alternatif yang berpotensi untuk dikembangkan, yaitu: Pariwisata budaya (cultural tourism), ekowisata (ecotourism), pariwisata bahari (marine tourism), pariwisata petualangan (adventure tourism), pariwisata agro (agrotourism), pariwisata pedesaan (village tourism), gastronomi (culinary tourism) dan pariwisata spiritual (spiritual tourism).

Menurut Inskeep (1991:27), ada 5 (lima) unsur penting yang harus dipenuhi untuk pengembangan suatu objek wisata, yaitu:

1) Daya Tarik, unsur ini merupakan faktor utama yang menarik wisatawan mengadakan perjalanan mengunjungi suatu tempat, baik suatu tempat primer yang menjadi tujuan utamanya, atau tujuan sekunder yang dikunjungi dalam suatu perjalanaan primer.

2) Prasarana wisata, unsur ini dibutuhkan untuk melayani wisatawan selama perjalanan wisata. Fasilitas ini cenderung berorientasi pada daya tarik wisata di suatu lokasi.

3) Sarana Wisata, unsur ini merupakan kelengkapan daerah tujuan wisata yang diperlukan untuk melayani kebutuhan wisatawan dalam menikmati perjalanan wisatanya.

4) Infrastruktur, unsur ini adalah pendukung fungsi sarana dan prasarana wisata, baik yang berupa sistem pengaturan maupun bangunan fisik diatas permukaan tanah dan dibawah tanah, dan

5) Masyarakat, Lingkungan, dan Budaya Daerah, tujuan wisata yang memiliki berbagai objek dan daya tarik wisata akan mengundang kehadiran wistawan.

\section{METODE PENELITIAN}

Penelitian ini bersifat deskriptif. Metoda deskriptif adalah penelitian yang mendeskripsikan atau menggambarkan/melukiskan fenomena atau hubungan antar fenomena yang diteliti dengan sistematis, faktual dan akurat (Natsir, 1998). Penelitian ini bertujuan untuk menggambarkan dengan lebih baik sifatsifat yang diketahui keberadaannya serta relevan dengan variable-variabel yang diteliti.

Populasi penelitian ini adalah pengguna obyek wisata (wisatawan) yang memanfaatkan obyek wisata Pantai Panjang serta masyarakat yang berlokasi di sekitar lokasi wisata Pantai Panjang di Kota Bengkulu yang telah berdomisili minimal selama lima tahunn. Hal ini dimungkinkan supaya warga disekitar Pantai Panjang dapat mengetahui dan merasakan manfaat langsung dari pengambangan objek wisata Pantai Panjang. Metode pengambilan sampel menggunakan teknik accidental sampling sebanyak 100 responden yang terdiri: wisatawan mancanegara 20 responden dan wisatawan nusantara 80 responden. Penyebaran kuisioner ini kepada wisatawan dilaksanakan pada akhir bulan Desember 2014 s.d. awal bulan Januari 2015, dengan pertimbangan pada waktu itu wisatawan banyak yang berkunjung di lokasi wisata pada waktu libur akhir tahun dan libur sekolah.

Jenis data yang digunakan adalah data primer dan data sekunder sebagai pendukung yang diperoleh dari instansi atau lembaga yang terkait dengan penelitian ini. Untuk mendapatkan data primer tersebut, digunakan teknik pengumpulan data; observasi, wawancara, dan kuisioner.

Adapun pengukuran variabel, dimensi, dan indikator masing-masing variabel yang digunakan dalam penelitian sebagai berikut.

Tabel 2. Variabel, Dimensi, dan Indikator masing-masing Variabel

\begin{tabular}{|c|c|c|}
\hline Variabel & Dimensi & Indikator \\
\hline \multirow{4}{*}{$\begin{array}{l}\text { ASPEK } \\
\text { PENGEMBANGAN } \\
\text { WISATA }\end{array}$} & Obyek dan Daya Tarik Wisata & $\begin{array}{l}\text { - Kualitas Air Laut } \\
\text { Keberadaan Pasir Putih } \\
\text { - Keberadaan Perahu Nelayan } \\
\text { - Keberadaan Tempat Mandi di Pantai } \\
\text { - Keberadaan Benteng Marlborough } \\
\text { - Keberadaan Wisata Kuliner }\end{array}$ \\
\hline & Sarana dan Prasarana Wisata & $\begin{array}{l}\text { - Transportasi ke Bengkulu } \\
\text { - Transportasi menuju kawasan wisata } \\
\text { - Air Bersih/WC Umum } \\
\text { - Tempat Pembuangan Sampah } \\
\text { Penerangan / Listrik } \\
\text { - Warung/restoran } \\
\text { - Fasilitas Bermain Anak-anak } \\
\text { Home Stay } \\
\text { - Jaringan Kominikasi (Sinyal HP) } \\
\text { Hotel/cafe }\end{array}$ \\
\hline & Pengelola & $\begin{array}{l}\text { - Tingkat Keamanan } \\
\text { - Sumber Informasi } \\
\text { - Ketersediaan Brosur Informasi Obyek Wisata } \\
\text { Harga Tiket Masuk } \\
\text { - Tingkat Kebersihan } \\
\text { - Tingkat Pelayanan Pengelola } \\
\text { Tingkat Kenyamanan }\end{array}$ \\
\hline & Kondisi Masyarakat & $\begin{array}{l}\text { - Sifat Keramahtamahan } \\
\text { Sifat Keterbukaan } \\
\text { - Sifat Tolong Menolong } \\
\text { - Sifat Terhadap Lingkungan }\end{array}$ \\
\hline
\end{tabular}


Untuk memetakan dan mengolah hasil penelitian dengan menggunakan Variabel, Dimensi, dan Indikator masing-masing Variabel untuk dalam menentukan strategi pengembangan kawasan wisata Pantai Panjang di Kota Bengkulu menggunakan teknik analisis SWOT untuk memaksimalkan kekuatan (strength) dan peluang (opportunitiess), serta dapat meminimalkan kelemahan (weakness) dan ancaman (treath). Kemudian menentukan lingkungan internal (IFAS) untuk mengetahui berbagai kemungkinan kekuatan dan kelemahan serta menganalisis lingkungan eksternal (EFAS) untuk mengetahui berbagai kemungkinan peluang dan ancaman.

\section{HASIL PENELITIAN}

\section{Lokasi dan Perspektif Wisatawan dan Masyarakat lokal}

Kawasan objek wisata Pantai Panjang berlokasi disisi barat Kota Bengkulu yang berjarak lebih kurang 3 kilo meter dari pusat kota dan pertokoan di Kota Bengkulu. Selain mengunjungi objek wisata Pantai Panjang wisatawan dapat juga langsung mengunjungi objek wisata benteng Marlborough yang merupakan peninggalan sejarah pemerintahan koloni Inggris ketika masa pendudukan di wilayah Bengkulu. Keberadaan benteng Marlborought di Tapak Paderi menambah daya tarik tersendiri untuk wisatawan yang berkunjung ke daerah ini. Dengan adanya image yang baik dan motto "Pantai Panjang Elok Nian" ini merupakan suatu keuntungan tersendiri untuk perkembangan pariwisata di kawasan ini.

Hasil pengamatan secara langsung di lokasi penelitian, diketahui kesadaran masyarakat lokal terhadap kebersihan lingkungan dan sanitasi lingkungan masih sangat kurang. Kondisi inilah menjadi tantangan utama pemerintah Propinsi Bengkulu dan Kota Bengkulu untuk dijadikan prioritas pertama dalam menjaga lingkungan wisata dengan jalan melibatkan semua stageholder yang terkait dibidang pariwisata, seperti: pemerintah, pengusaha perjalanan wisata, perhotelan, wisatawan, dan masyarakat yang berdomisili di sekitar kawasan wisata Pantai Panjang dengan cara memberikan penyuluhan dan pengarahan kepada masyarakat tentang pentingnya arti lingkungan yang bersih dan sehat untuk menunjang pembangunan pariwisata di Kota Bengkulu

Berdasarkan tabel deskripsi tanggapan dari sampel sebanyak 100 responden dari ke empat aspek yang diteliti, adalah:

1. Analisis terhadap obyek dan daya tarik wisata adalah $76 \%$ menyatakan sangat tertarik, $30 \%$ mengatakan menarik, dan hanya $4 \%$ menaggapi tidak menarik terhadap obyek wisata pasir putih, tempat pemandian air laut dan keberadaan Benteng Marlbrough di kawasan Pantai Panjang.

2. Analisis terhadap kesadaran masyarakat tentang pentingnya kebersihan dan kesehatan lingkungan 92\% responden menaggapi tidak baik dan $8 \%$ responden mengatakan kurang baik.

3. Analisis terhadap pengelolaan dan kebersihan objek wisata adalah $94 \%$ responden menyatakan tidak baik, $4 \%$ responden menyatakan kurang baik, dan hanya $2 \%$ responden menyatakan baik.

4. Analisis terhadap kondisi sosial masyarakat untuk kategori "ramah tamah" adalah 50\% sangat baik, $42 \%$ menyatakan baik, dan yang menjawab kurang baik sebesar $8 \%$, sedangkan untuk kategori sifat "keterbukaan" terhadap wisatawan adalah sangat baik $42 \%$ responden, baik sebesar 54\%, dan 4,\% responden menyatakan kurang baik.

Hasil penelitian secara keseluruhan mengenai tanggapan wisatawan terhadap seluruh aspek pengembangan kawasan objek wisata Pantai Panjang Kota Bengkulu, berdasarkan rumus interval Sturges (Sugiono, 2006) dari rerata ke empat aspek yang diteliti adalah:

a. Aspek obyek dan daya tarik wisata $=3,15$ (baik).

b. Aspek sarana dan prasarana wisata $=2,13$ (kurang baik).

c. Aspek pengelolaan obyek wisata $=2,18$ (kurang baik),

d. Aspek kondisi masyarakat $=2,60$ (baik).

Dengan total rerata ke empat aspek $(A+B+C+D)$ yang dinilai $=2,60$ (baik). Kondisi ini dapat kita lihat dilapangan bahwa jumlah wisatawan mancanegara maupun nusantara setiap tahunnya terus meningkat. Merujuk pada tanggapan persepsi wisatawan dan masyarakat lokal, menunjukkan bahwa potensi objek wisata Pantai Panjang sangat pantas untuk dikembangkan sebagai destinasi objek pariwisata di Kota Bengkulu.

Untuk mengetahui letak kuadran strategi berdasarkan formulasi sumbu X dan Y, dimana sumbu X adalah EFAS (Peluang - Ancaman) dan sumbu Y adalah IFAS (Kekuatan - Kelemahan), dapat dilihat pada gambar 1 berikut. 
Gambar 1. Grafik Letak Kuadran Analisis SWOT

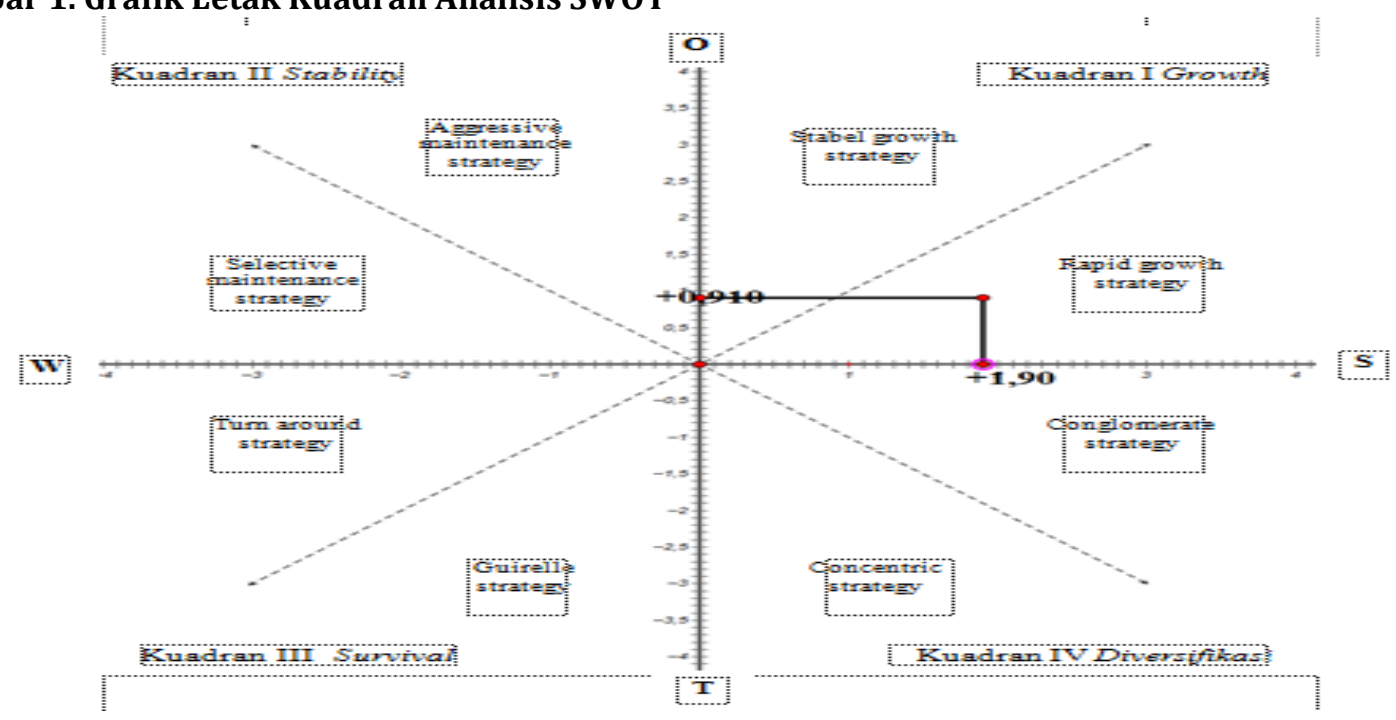

Berdasarkan formulasi letak kuadran pada gambar 1 diatas, strategi yang mendesak untuk dilaksanakan dalam rangka pengembangan kawasan pariwisata Pantai Panjang Bengkulu dalah terletak di kuadran I atau terletak antara peluang ekternal dan kekuatan internal (strategi pertumbuhan) yaitu strategi yang didesain untuk mencapai pertumbuhan jumlah kunjungan wisatawan (frekuensi kunjungan dan asal daerah wisatawan), aset (obyek dan daya tarik wisata, prasarana dan sarana pendukung), pendapatan (retribusi parkir dan jumlah yang dibelanjakan).

Dari analisis SWOT berdasarkan analisis Kekuatan-Kelemahan (IFAS) diperoleh skor +0,910 dan nilai skor Peluang-Ancaman skor EFAS adalah $\quad+1,90$ dari analisis SWOT, maka pemetaan strategi pengembangan Pantai Panjang terletak pada kuadran satu, yaitu strategi SO (antara peluang ekternal dan kekuatan internal) atau strategi pertumbuhan. Strategi pertumbuhan (growth) atau strategi Rapid growth strategy (strategi pertumbuhan cepat), adalah suatu strategi untuk meningkatkan laju pertumbuhan kunjungan wisatawan dengan waktu lebih cepat (tahun kedua lebih besar dari tahun pertama dan selanjutnya), peningkatan kualitas yang menjadi faktor kekuatan untuk memaksimalkan pemanfaatan semua peluang.

\section{Program Pengembangan Kawasan Wisata Pantai Panjang Kota Bengkulu}

Berdasarkan analisis SWOT, pemerintah Kota Bengkulu harus dapat segera membuat rencana program jangka pendek maupun jangka panjang untuk mengembangkan objek wisata Pantai Panjang, supaya dapat dijadikan salah satu sektor andalan dan juga merupakan sumber Pendapatan Asli Daerah Kota Bengkulu. Hasil penelitian terhadap persepsi wisawatawan dan masyarakat lokal terhadap pengembangan kawasan Pantai Panjang Kota Bengkulu, adalah sebagai berikut:

\section{Penataan Wisata Kuliner}

Penataan dan pengembangan obyek wisata Pantai Panjang Kota Bengkulu, yang menonjolkan potensi alam pantai dan potensi keragaman biota ikan laut sebagai unsur dominan, menuntut keselarasan antara kebutuhan fungsional dengan lingkungan alam, sehingga perlu ada desain dengan konsep ekoarsitektur. Kawasan obyek wisata Pantai Panjang Bengkulu, yang selama ini dikenal sebagai obyek wisata kuliner makanan laut, dalam waktu dekat perlu dikembangkan ke arah yang lebih baik dan profesional .

Untuk menuju kawasan obyek wisata kuliner makanan ikan laut, maka perlu adanya penataan; lingkungan wisata, pedagang, nelayan dan warung-warung yang ada di kawasan Pantai Panjang Bengkulu. Selain itu, juru masak serta lingkungan warung serta cara menyajikan juga harus sopan, bersih dan sebagainya. Untuk melakukan itu semua, Dinas Kebudayaan dan Pariwisata Kota Bengkulu bekerja sama dengan pihak travel agent dan perhotelan dapat memberi penyuluhan kepada semua pelaku usaha kuliner.

\section{Penataan Perhotelan}

Penghasilan terbesar dari pengelolaan sebuah hotel adalah penyewaan kamar dan kegiatan lainnya seperti kegiatan seminar, simposium, dan acara resepsi pernikahan. Pembangunan perhotelan di kawasan Pantai Panjang perlu ditata sedemikian rupa untuk menunjang kenyamanan para 
wisatawan yang menginap di lokasi wisata. Peningkatan jumlah tamu yang menginap di hotel hanya terjadi pada hari-hari libur terutama pada tahun baru, acara perayaan Tabot, dan lainnya.

Penataan perhotelan yang paling penting adalah pada area hotel supaya ada ruang-ruang yang membentuk area menjadi satu kesatuan fungsi. Setiap area harus dibangun hubungan antar ruang mikro yang akan membentuk area makro berdasarkan analisis hubungan ruang mikro, sehingga jika keseluruhan ruang digabungkan akan menjadi satu organisasi ruang keseluruhan hotel resort. Secara keseluruhan organisasi ruang pada hotel dimulai dari enterance pada area depan hingga masuk ke dalam ruang-ruang dalam kawasan hotel tersebut.

Bangunan dan konsep hotel yang sudah ada sekarang tidak perlu di relokasi namun kalau ada pemugaran atau rebuilding harus disesuaikan dengan konsep rencana penataan hotel yang telah direncanakan. Demikian pula dengan hotel-hotel yang akan dibangun harus disesuaikan dengan standardisasi hotel-hotel di yang ada kawasan Pantai Panjang Kota Bengkulu.

\section{Penataan Pedagang Kaki Lima}

Sebagai objek wisata Kota Bengkulu yang memiliki potensi besar di sektor pariwisata, penataan sarana penunjang objek wisata Pantai Panjang di Kota Bengkulu harus dilakukan secara permanen, misalnya penataan Pedagang Kaki Lima (PKL) yang berada dalam kawasan Pantai Panjang. Sekarang ini di Pantai Panjang Kota Bengkulu banyak sekali terdapat PKL yang tidak teratur berjualan di kawasan objek wisata. Penataan terhadap PKL di Pantai Panjang Kota Bengkulu harus manusiawi dengan tidak akan mengabaikan hajat hidup para PKL. Maksudnya, para pedagang boleh berdagang namun ada upaya penanganan para PKL perlu diatur dan dikelola supaya lokasi kawasan wisata tertata dengan rapi dan tidak mengganggu wisatawan untuk berkunjung disana. Misalnya para PKL dibangun dan diberikan tempat khusus oleh pemerintah dan membongkar warung-warung yang semrawut dan tidak memenuhi standar kebersihan dan penerangan untuk wisata.

Untuk melakukan penataan pedagang kaki lima, perlu adanya koordinasi dan pertemuan dengan para pemilik PKL dengan pemerintah. Pekerjaan ini bukan hal mudah, karena banyak masyarakat yang memiliki kepentingan mata pencaharian di Pantai Panjang Kota Bengkulu. Dinas Pariwisata dan Ekonomi Kreatif Kota Bengkulu harus melakukan koordinasi dan berbicara dengan tokoh masyarakat dan para PKL di objek Wisata Pantai Panjang Kota Bengkulu untuk membangun semangat kebersamaan dalam mengembangkan kawasan wisata Pantai Panjang.

\section{Pengamanan Kawasan Pantai}

Keamanan kawasan Pantai Panjang di Kota Bengkulu perlu ditingkatkan, yang harus berbanding lurus dengan luas wilayah dan jumlah personel SAR, yang selama ini belum terpenuhi. Pengawasan objek wisata Pantai Panjang membutuhkan keterampilan dan dukungan peralatan yang memadai dari Tim SAR Pantai Panjang sehingga dapat menciptakan rasa aman dan nyaman bagi wisatawan. Pengamanan objek wisata lainnya adalah keamanan tindakan kriminal dari penjahat yang sering terjadi pada malam hari dan kecelakaan lalu lintas di sepanjang jalan Pantai Panjang yang berujung dengan maut.

Untuk masalah pengamanan kawasan wisata, yang perlu dilakukan adalah adalah membuat poskoposko keamaan minimal ada dua di objek wisata pantai yaitu: 1 (satu) posko keamanan untuk keamanan dan ketertiban objek dan 1 (satu) lagi posko keamanan pengunjung laut yang berada pada kawasan rawan di objek Pantai Panjang. Pengamanan lainnya adalah pemasangan ramburambu/larangan tempat berbahaya untuk tempat mandi para pengunjung. Antisipasi ini harus segera dilakukan, mengingat kecelakaan sering terjadi pada waktu tahun baru/liburan sekolah dengan pengunjung yang sangat banyak terutama dari luar kota

\section{Penataan Olahraga Pantai}

Sebagai sarana olah raga di Pantai Panjang Kota kini telah dibangun Sport Center, namun pemanfatannya masih sangat terbatas hanya dilaksanakan pada event tertentu saja. Pemanfaatan lainnya adalah olah raga jalan santai yang banyak dilakukan oleh para pengunjung terutama pada pagi hari minggu/hari libur lainnya. Namun demikian dalam penataan sarana olah raga pantai haruslah dibuat sarana olah raga pantai seperti; volly pantai, surfing dan lain-lainnya.

Penataan olah raga pantai, harus dibarengi dengan pembangunan sarana dan prasarana olah raga lainnya, dengan mengikuti kategori olah raga yang sesuai dengan objek wisata Pantai Panjang Kota Bengkulu.

\section{KESIMPULAN}

1. Tanggapan persepsi wisatawan terhadap pengembangan wisata Pantai Panjang adalah baik yaitu dengan total nilai rerata 2,60 , namun ada beberapa sub aspek yang masih sangat memprihatinkan adalah sarana dan prasarana tempat pembuangan sampah (skor 1,08), tingkat kebersihan tempat wisata (skor 1,08), dan kondisi masyarakat terhadap lingkungan (skor 1,54) yang tidak baik. 
2. Faktor-faktor internal yang mendukung pengembangan pariwisata Pantai Panjang adalah keberadaan Benteng Marlbrought, image tempat wisata yang sudah terkenal sejak zaman kolonial, sifat keterbukaan, keamanan, dan kemudahan mencapai lokasi karena dekat dengan pusat kota. Sementara yang menghambat adalah belum adanya pusat informasi wisata, belum ada tempat sampah sehingga sampah masih banyak yang berserakan, sifat terhadap lingkungan yang sangat rendah, SDM bidang pariwisata masih rendah, dan belum memadai infrastruktur pendukungnya.

3. Faktor-faktor eksternal yang mendukung pengembangan tempat wisata Pantai Panjang adalah letaknya yang strategis, perkembangan teknologi dan informasi, regulasi, serta tingginya potensi dan minat wisatawan. Sementara yang menghambat adalah tidak adanya pembatas lokasi wisata dengan tempat pemukiman masyarakat sehingga wisatawan/warga bebas keluar masuk tempat wisata, belum adanya transportasi umum yang langsung menuju lokasi wisata, interusi budaya dan pengrusakan lingkungan.

4. Pengembangan kawasan wisata Pantai Panjang berdasarkan SWOT adalah promosi/pemasaran tempat wisata dengan membangun jaringan dengan wisata lain, bekerjasama dengan agen perjalanan, dan membuat website khusus. Sedangkan yang menjadi perioritas pengembangan wisata Pantai Panjang adalah pembenahan tempat pembuangan sampah, gazebo/shelter, tempat penyedaan air bersih (tidak asin), tempat parkir, pintu masuk tempat wisata, manajemen pengelolaan wisata, dan lain-lain.

5. Perioritas utama program pengembangan objek wisata Pantai Panjang Bengkulu adalah penataan wisata kuliner, penataan perhotelan, penataan pedagang kali lima, penataan keamanan kawasan pantai, dan penataan objek olah raga pantai.

\section{DAFTAR PUSTAKA}

Ateljevic, Jovo (2007). Small Tourism Firms and Management Practices in New Zealand: The Centre Stage Macro Region. Tourism Management 28 (2007) 307-316

Cawley, Mary and Gillmor, Desmond (2007). A. Integrated Rural Tourism: Concepts and Practice. Annals of Tourism Research, Vol. 35, No. 2, pp. 316-337, 2008

Chang. Peter R. (2007). Tourism Management In the 21 St Century. Editor Nova Science Publishers, Inc.

Dinas Pariwisata dan Kebudayaan Kota Bengkulu, (2013). Rencana Induk Pengembangan Objek Wisata (RIPOW). PT. Dezet Igenering Consultant.

Hunger, David dan Wheelen L. Thomas. (2000). Management Strategis; Alih Bahasa Julianto Agung S. Edisi I-Yogyakarta: Andi

Inskeep, Edward. (1991). Tourism Planning: An Intergrated and sustainable Approach. Van Nostrand Reinhold.New York, Inc

Liu, Abby (2006). Tourism in Rural Areas: Kedah, Malaysia. Tourism Management 27 (2006) 878-889

Natsir, Mohammad, (1998). Metode Penelitian. Jakarta. Ghalia Indonesia.

Pender, L. and R. Sharpley. (2005). The management of tourism. SAGE Publications Ltd. London.

Rangkuti, Freddy. (1996). Analisis SWOT Teknik Membedah Kasus Bisnis, Jakarta: PT Gramedia Pustaka Umum

Sugiyono (2009). Metode Penelitian Bisnis (Pendekatan Kuantitatif, Kualitatif dan R\&D). Alfabeta. Bandung

Suwantoro, Gamal, (1997). Dasar-dasar Pariwisata, Yogyakarta: ANDY

Swarbrooke, J. 1998. Sustainable Tourism Management. London: CABI Publishing 
Tosun, C. (2006). Expected nature of community participation in tourism development. Tourism Management $27,493-504$

Sull, D. (1999) Case study: easy Jet's $\$ 500$ million gamble. European Management Journal, 17(1), February: 20-38.

Tribe's (1997: 13Tribe, J. (1997) Corporate Strategy for Tourism. London: Thomson Learning.

Yoeti, Oka, A (1997). Perencanaan dan Pengembangan Pariwisata. Jakarta: PT. Pradnya Paramitha

Pender, Lesley and Sharpley, Richard. (2005). The Management of Tourism. Sage Publication London.

Zeng, Benxiang and Ryan, Chris (2011). Assisting the poor in China through tourism development: A review of researc. Tourim Management 33(2012) 239-248 